\title{
A PROBLEM WITH ECOLOGICALLY SUSTAINABLE DEVELOPMENT IN AUSTRALIAN WATERS
}

\author{
by F. R. Harden Jones
}

(with one table)

\begin{abstract}
HaR J J NeS, F.R., 2000 (31:v): A problem with ecologically sustainable development in Australian waters. In Banks, M.R. \& Brown, M.J. (Eds): TASMANIA AND THESOUTHERNOCEAN Pap. Proc. R. Soc. Tasm. 133(3): 17-19.

https://doi.org/10.26749/rstpp.133.2.17 ISSN 0080-4703. Institute of Antarctic and Southern Ocean Studies, GPO Box 252-77, Hobart, Tasmania, Australia 7001.

A federal court decision has ruled that social and community issues are irrelevant to the Australian Fisheries Management Authority in pursuing its statutory objecrives laid down in the Fisheries Management Act 1991. The matter is discussed in relation to recent policy statements put forward by Australian Governments.
\end{abstract}

Key Words: fisheries management, AFMA, Bannister Quest, ecologically sustainable development, national strategy, Australia's Oceans Policy.

\section{INTRODUCTION}

The Australian Fisheries Management Authority (AFMA) undertakes the Commonwealth's fishery responsibilities in Australia's Exclusive Economic Zonewhich includes the sea areas around Australia's Subantarctic islands.

AFMA has been receiving a lot of flak recently, both in and out of the courts. Tasmanian fishers have problems with AFMA over the allocation of trevalla or blue eye (Hyperoglyphe antarctica Carmichael) quotas. In Hobart, George Mure has been vociferous on this matter - and on the Mure-path - for several months.

Richard Stevens was until recently the Managing Director of AFMA. He was reported in the newspapers as saying that social and community matters were of no concern to AFMA, or words to that effect. I was surprised. But $\mathrm{Mr}$ Stevens is correct, and he was correctly reported in the press.

AFMA's position follows from Bannister Quest Pty Ltd v. Australian Fisheries Management Authority (1997) 77 FCR 503-551 before Drummond J on 14 August 1997 at Brisbane (hereafter Bannister Quest). In this case Mr Will Nichols (a Melbourne fisher) appealed against an AFMA decision that he could not use a vessel over $32 \mathrm{~m}$ in length in the South East Fishery. AFMA appeared to have refused entry because operators with smaller vessels might be disadvantaged.

\section{AFMA'S OBJECTIVES}

AFMA was set up under the Fisheries Administration Act 1991 and AFMA's objectives are set out in the Fisheries Management Act 1991 (hereafter FM Act) Section 3. This section, dealing with objectives, reads as follows:

3. (1) The following objectives must be pursued by the Minister in the administration of this Act and by AFMA in the performance of its functions: (a) implementing efficient and cost-effective fisheries management on behalf of the Commonwealth; and

(b) ensuring that the exploitation of fisheries resources and the carrying on of any related activities are conducted in a manner consistent with the principles of ecologically sustainable development, in particular the need to have regard to the impact of fishing activities on non-target species and the marine environment; and

(c) maximising economic efficiency in the exploitation of fisheries resources; and

(d) ensuring accountability to the fishing industry and to the Australian community in AFMA's management of fisheries resources; and

(e) achieving government targets in relation to the recovery of the costs of AFMA.

(2) In addition to the objectives mentioned in subsection (1), or in section 78 of this Act, the Minister, AFMA and Joint Authorities are to have regard to the objectives of:

(a) ensuring, through proper conservation and management measures, that the living resources of the AFZ are not endangered by overexploitation; and

(b) achieving the optimum utilisation of the living resources of the AFZ;

but must ensure, as far as practicable, that measures adopted in pursuit of those objectives must not be inconsistent with the preservation, conservation and protection of all species of whales. 


\section{TRUE CONSTRUCTION OF AFMA'S OBJECTIVES}

Here I will follow the text of Mr Justice Drummond in Bannjster Quest without reference to other legal authorities.

There is a difference in the wording of Section 3 (1) and Section 3 (2). Section 3 (1) reads "... must be pursued..." This is a statutory imperative and AFMA would be in breach of its duty if the five objectives (a to e) were not pursued. While all the objectives in Section 3 (1) are of equal importance

there will be cases in which the Minister may give varying degrees of weight and emphasis to this or that objective. So long as each objective is pursued, there will be no breach of duty. But if one of the objectives is not pursued at all, then that will not be the case. [Bannister Quest, 513 E, F, G; 514 A.]

In contrast Section 3 (2) of the FM Act reads "... are to have regard to ..." and is less demanding. The objectives in Section 3 (2) of the FM Act are the same as those in Section $5 \mathrm{~B}$ of the Fisheries Act 1952. And in the FM Act the phrase "optimum utilisation" in Section 3 (2) contrasts with "maximise economic efficiency" in Section 3 (1).

\section{MR JUSTICE DRUMMOND'S DECISION}

In making a decision in Bannister Quest, Mr Justice Drummond had to decide the true meaning of the objectives in Section 3 (1) of the FM Act and his interpretations of Section 3 (1) (b) and (c) are relevant to the theme of this paper.

I will take Section 3 (1) (c) first. What does "maximising economic efficiency in the exploitation of fisheries resources" mean in the context of the FM Act? As Section (1) (c) is a statutory obligation which AFMA has to pursue, the meaning of the phrase should be determined by statutory construction and not by reference to textbook economics (Bannister Quest, 514 B, C).

Mr Justice Drummond considered much of the language in Section 3 (1) of the FM Act to be "obscure and ambiguous" (Bannister Quest, 514 E, F). Curiously, neither "economic efficiency" nor "ecologically sustainable development" is defined in the FM Act. Under these circumstances the Acts Interpretation Act 1901 Section 15 $\mathrm{AB}$ indicates the extrinsic material that may be used in the interpretation of obscure and ambiguous Acts.

Briefly, the material must have been before Parliament, or its members, before the Bill was enacted. Government policy statements and the Minister's speech at the second reading are among the material that may be relied on.

From the Minister's (then Mr John Kerin) speech and the Government Policy Statement "New Directions", Mr Justice Drummond concluded that the concept of "economic efficiency" referred to in Section 3 (1) (c) of the FM Act was

productive efficiency in the sense of maximising output at least cost to the operators of the vessels comprising the fishing industry ... [Bannister Quest, $515 \mathrm{E}, \mathrm{F}$, G.]

Furthermore, he concluded that, in pursuing the objective in Section 3 (1) (c), AFMA is to be concerned with profits
TABLE 1

Dates of events or publication of documents relevant to Ecologically Sustainable Development

\begin{tabular}{lll}
\hline Year & Month & \multicolumn{1}{c}{ Event } \\
1983 & & $\begin{array}{l}\text { Fisheries Act } 1952 \text { reprinted } \\
\text { WCED, Our Common Future } \\
\text { (Brundtland Report) published }\end{array}$ \\
1987 & & New Directions published \\
1989 & Dec & ESD WG Fisheries first meeting \\
1991 & Oct & ESD WG Fisheries last meeting \\
1991 & Oct & ESD WG Fisheries report published \\
1991 & Nov & FA Act and FM Act assented, \\
1992 & & National Strategy for ESD published \\
1998 & Mar & Oceans Policy (Report) published \\
1998 & Dec & Oceans Policy 1 published \\
1998 & Dec & Oceans Policy 2 Specific Sectoral \\
& & Measures published \\
\hline
\end{tabular}

at the industry level and not with the situations of individual fishers; and that

there is no room for AFMA, in seeking to maximise economic efficiency in the exploitation of fishery resources, to take into account social and equity considerations ... [Bannister Quest, 519 E, F, G.]

I now come to Section 3 (1) (b) of the FM Act, which refers to the principles of ecologically sustainable development. The dates of some events and publications are summarised in table 1. Only New Directions, the Government policy statement, satisfies the conditions of the Acts Interpretation Act relating to the use of intrinsic material. But "ecologically sustainable development" (ESD) appears to be mentioned only once in New Directions, on p. 1, para. 2, lines 3-4. "Ecologically Sustainable Development" does not even appear in the Glossary.

Following New Directions and the Minister's second reading speech to Parliament, $\mathrm{Mr}$ Justice Drummond decided that

Section 3 (1) (b), on its true construction, requires AFMA, in pursuing this objective in the performance of its functions, to limit its consideration to matters that relate to two things, ensuring the biological sustainability of fish stocks and ensuring the protection of the marine environment upon which those fish resources depend. [Bannister Quest, 526 E.]

So social, community and equity consideration and the like are irrelevant to AFMA in the pursuit of its statutory objectives. Mr Will Nichols won his appeal and his costs.

\section{FISHERIES MANAGEMENT, ESD AND THE FUTURE}

But the Judge's interpretation of the true meaning of Section 3 (1) (b) of the FM Act may not be what governments had in mind. Thus the National Strategy for ESD, referring to the guiding principles of $\mathrm{ESD}$, indicates (Anon. 1992: 8-9) that the 
decision making processes should effectively integrate both long and short term economic, environmental, and social and equity considerations ...

and (Anon. 1992: 8-9) that the

... guiding principles and core objectives need to be considered as a package. No objective or principle should predominate over the others. A balanced approach is required that takes into account all the objectives and principles to pursue the goal of ESD.

The report of the Ministerial Advisory Group on Australia'sOceans Policy notes (Anon. 1998a: 21, para. 6) that

management for ecological sustainable development of the fisheries industry requires consideration of the economic, social and environmental aspects of all fishery sectors.

And the National Strategy for ESD includes a very clear statement of intent (Anon. 1992: 27) that governments will

review, and where necessary amend, fisheries legislation to ensure it provides the basis for managing the fishery resource in ways which are consistent with the principles of ESD.

On p.27 (at dot point 3) in the National Strategy, a distinction is implied between "an ecosystem approach" and "the principles of ESD". There is indeed a difference between them. An ecosystem approach to management is concerned with the resource (and its environment) that fishers pursue. But ESD must also include the resources that industry uses at the catching, processing, marketing and consumer levels. And all these levels, or sectors, involve social, community and equity concerns.

However, it now seems likely that the Government will limit its review of fisheries laws and regulations to streamlining and minimising compliance costs for small businesses (Anon 1998c: 10, col. 1, dot point 7).

As the CSIRO member on the Fisheries ESD Working Group (WG F ESD 1991), I attended 14 of the 16 meetings and kept detailed notes of the discussions: some were explosive.

At the second meeting, Dr Andrew Constable gently drew our attention to the need to develop alternative management strategies in the absence of data whose cost of collection could exceed the value of the fishery.

At the third meeting, there were many objectors, led by Dr Bob Kearney (then Director of the NSW Fisheries
Research Institute at Cronulla), to the concept of "maximising" economic efficiency when "optimising" seemed more appropriate. Later Mr Geoff Gorrie, Director of the Australian Fisheries Service, carried out "damage control" in respect of the use of "maximisation" in New Directions and finally conceded that this was really a "constrained maximisation".

At the fourth meeting, Dr Bruce Davis gave as his view that the economic and social factors associated with ESD might prove to be more difficult than the "fishery" problems. Subsequent events bear out his concerns.

Finally, my notes of the fifth meeting record that there was a very loud and prolonged argument over definitions. I kept quiet: when the lions roar, it behoves the lesser animals to remain silent. But the experience stimulated me to start work on the glossary and anthology that was later published (Harden Jones 1994) with assistance from IASOS and the Fisheries Research and Development Corporation.

I think, indeed I rather hope, that there will be more arguments in the future.

\section{REFERENCES}

ANON., 1989: NEW DIRECTIONS FOR COMMONWEALTH FISHERIES MANAGEMENT IN THE 1990S. AGPS, Canberra: $114 \mathrm{pp}$.

ANON., 1992: NATIONAL STRATEGY FOR ECOLOGICALLY SUSTAINABLE DEVELOPMENT. AGPS, Canberra: $128 \mathrm{pp}$.

ANON., 1998a: AUSTRALIA'S OCEANS POLICY. Report of the Ministerial Advisory Group on oceans policy. Environment Australia, Canberra: $49 \mathrm{pp}$.

ANON., 1998b: AUSTRALLA'S OCEANS POLICY 1. Environment Australia, Canberra: $48 \mathrm{pp}$.

ANON., 1998c: AUSTRALLA'S OCEANS POLICY 2. Specific Sectoral Measures. Environment Australia, Canberra: $48 \mathrm{pp}$.

Harden JONES, F.R., 1994: FISHERIES ECOLOGICALLY SUSTAINABLE DEVELOPMENT: TERMS AND CONCEPTS. IASOS, University of Tasmania, Hobart, Tasmania: 205 pp.

WCED, 1987: OUR COMMON FUTURE. (The Brundtland Report). World Commission on Environment and Development, Oxford University Press: $400 \mathrm{pp}$.

WG F ESD, 1991: ECOLOGICALLY SUSTAINABLE WORKING GROUPS. Final report Fisheries. AGPS, Canberra: $202 \mathrm{pp}$.

(accepted 5 July 1999) 